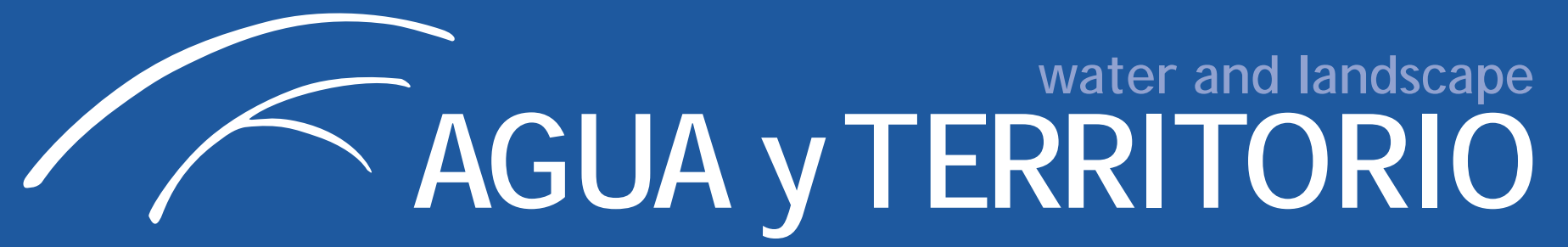

\title{
0 caminho das águas na América Portuguesa: a rede de abastecimento de Mariana no século XVIII
}

\author{
El camino de las aguas en la América portuguesa: \\ la red de abastecimiento de Mariana en el siglo XVIII \\ Water Paths in Portuguese America:
The Mariana Water Supply Network in the 18th Century
}

Denise M. Ribeiro-Tedeschi

Universidade Estadual de Campinas. Campinas, Brasil. dedetedeschi@yahoo.com.br

\begin{abstract}
Resumo - A proposta deste artigo é apresentar a rede de abastecimento de áqua construída em Mariana na segunda metade do século XVIII. Mariana, a única cidade da Capitania de Minas Gerais, nesse período, integrava o circuito do ouro na América Portuguesa. 0 serviço de fornecimento de água à cidade só veio a se consolidar mais de meio século após a fundação do povoado, quando a Câmara, órgão local responsável pela administração da municipalidade, financiou as obras necessárias para conduzir a água para o consumo urbano. Nosso obj etivo consiste em apresentar o processo construtivo da rede hídrica de fornecimento de Mariana: 0 momento de edificação, a estrutura material e os recursos utilizados para administrar o serviço de abastecimento de água. Contratos de obras da Câmara e vestígios materiais remanescentes constituem o conjunto de documentos e fontes investigados nesta pesquisa.

Resumen - La propuesta de este artículo es presentar la red de abastecimiento de agua construida en Mariana en la segunda mitad del siglo XVIII. La única ciudad de la Capitanía de Minas Gerais en este período integraba el circuito del oro en la América portuquesa. El servicio de suministro de aqua a la ciudad sólo vino a consolidarse más de medio siglo después de la fundación de la ciudad, cuando la Cámara -órgano local responsable de la administración de la municipalidad-financió las obras necesarias para conducir el agua para el consumo urbano. Nuestro objetivo consiste en presentar el proceso constructivo de la red hídrica de suministro de Mariana: el momento de su edificación, la estructura material y los recursos utilizados para administrar el servicio de abastecimiento de agua. Contratos de obras de la Cámara y vestigios materiales remanentes constituyen el conj unto de fuentes investigadas para realizar este estudio.

Abstract - This article examines the water supply network built in the Brazilian city of Mariana in the second half of the 18th century. Mariana was the only city of the captaincy of Minas Gerais in that period to be part of Portuguese America's gold circuit. The water supply service to the city was developed more than half a century after the town was founded, when the câmara or city council -the local body responsible for administering the municipality-financed the infrastructure necessary to supply water for urban consumption. Our analysis focuses mainly on the construction phase, the physical infrastructure and the resources used to manage the water supply service. The câmara's work contracts and the material remains of the network system constitute the sources tapped for this research.
\end{abstract}

\begin{abstract}
Palavras-chave: rede de abastecimento de água, aqueduto, América portuguesa, Mariana (Minas Gerais) Palabras clave: red de abastecimiento de agua, acueducto, América portuguesa, Mariana (Minas Gerais) Keywords: water supply network, aqueduct, Portuguese America, Mariana (Minas Gerais)
\end{abstract}

